Article

\title{
Development of a Synthetic Synovial Fluid for Tribological Testing
}

\author{
Emely Lea Bortel ${ }^{1,2}$, Baptiste Charbonnier ${ }^{1}$ and Roman Heuberger ${ }^{1, *}$ \\ 1 RMS Foundation, Bischmattstrasse 12, CH-4500 Bettlach, Switzerland; \\ E-Mails: emely.bortel@mpikg.mpg.de (E.L.B.); charbonnier@emse.fr (B.C.) \\ 2 TU Hamburg, Schwarzenbergstrasse 95, D-21073 Hamburg, Germany \\ * Author to whom correspondence should be addressed; \\ E-Mail: roman.heuberger@rms-foundation.ch; Tel.: +41-32-644-14-74; Fax: +41-32-644-11-76.
}

Academic Editor: Ille C. Gebeshuber

Received: 10 July 2015 / Accepted: 18 November 2015 / Published: 1 December 2015

\begin{abstract}
Wear tests of joint prostheses are usually performed using bovine calf serum. The results from different laboratories are hardly ever comparable as, for example, the protein concentration and the protein composition of the serum-based test liquids vary. In addition, the viscosity of these test liquids is similar to that of water and does not match the more viscous synovial fluid. The present work was aimed at developing a synthetic synovial fluid as an alternative to the existing test liquids. Improved consistency and reproducibility of results at a similar price were required. Hyaluronic acid (HA), the lyophilized proteins bovine serum albumin (BSA) and immunoglobulin $G(\operatorname{IgG})$, the phospholipid lecithin (PL) and salts were applied in a stepwise approach to replace the actually used test liquid based on newborn calf serum. The in vitro results obtained with ultra-high-molecular-weight polyethylene (UHMWPE) pins sliding against CoCrMo discs revealed that the developed synthetic synovial fluid fulfils the set requirements: increase of viscosity, reasonable cost, improved consistency and wear particles which resemble the ones found in vivo. The developed synthetic synovial fluid with $3 \mathrm{~g} / \mathrm{L} \mathrm{HA}, 19 \mathrm{~g} / \mathrm{L} \mathrm{BSA}$, $11 \mathrm{~g} / \mathrm{L} \mathrm{IgG}, 0.1 \mathrm{~g} / \mathrm{L} \mathrm{PL}$ and Ringer solution is a more realistic alternative to the used serum-based test liquid.
\end{abstract}

Keywords: synthetic synovial fluid; viscosity; tribology; prosthesis testing; UHMWPE; polyethylene; CoCrMo 


\section{Introduction}

Preclinical wear tests are necessary to predict the in vivo performance of joint prostheses. Conditions that mimic the in vivo situations are indispensable for significant and reliable results. The arising motion and load inside the joints during different movements are well understood [1,2] and the motion and load cycles for walking are normed by the ISO standards 14242-1/-3 and 14243-1/-3 for the simulation of hip and knee joints, respectively [3-6].

Different test liquids are commonly used for wear tests. The 2002 version of the ISO standard 14242-1 for hip joint simulators recommended the use of calf serum $(25 \% \pm 2 \%)$ diluted with deionized water. In this case, the problem arose that the starting protein concentrations of calf sera varied, e.g., from $30-50 \mathrm{~g} / \mathrm{L}$ for foetal bovine serum, from $55-80 \mathrm{~g} / \mathrm{L}$ for newborn calf serum (NCS) or from $63-83 \mathrm{~g} / \mathrm{L}$ for bovine serum. Therefore the protein concentrations in the final test liquid varied. Since 2012, the calf serum should be diluted with deionized water to a protein concentration of $30 \pm 2 \mathrm{~g} / \mathrm{L}$, but, since 2014, differing protein concentrations can be used if justified with in vivo data. In contrast, a dilution to $20 \mathrm{~g} / \mathrm{L}$ is recommended by the actual ISO 14243-1:2009 standard for knee joint simulators. A concentration of $30 \mathrm{~g} / \mathrm{L}$ is in agreement with studies of synovial fluids in hip prostheses where protein concentrations between 20 and $40 \mathrm{~g} / \mathrm{L}$, with an average at around $30 \mathrm{~g} / \mathrm{L}$ were found [7-10]. However, tests reported in the literature use different test liquids e.g., based on pure calf serum [11,12], 90\% bovine serum [13], 1:1 dilution [14], $30 \mathrm{~g} / \mathrm{L}$ [15,16], 25\% dilution [17] or pure water [18], which makes a comparison of the results difficult. In addition, the protein composition depends on the origin, race, age, nutrition etc. and might influence the outcome of a wear test too.

McNulty et al. investigated the effect of the protein concentration on the wear of differently crosslinked polyethylene liners against CoCrMo heads in a three-laboratory round robin test [19]. The reproducibility between the laboratories was poor because of differences in the test parameters of the individual laboratories. Nevertheless, they found that the wear rate doubled depending on the concentration, whereas usually lower wear was observed with higher protein concentration. In other studies with ultra-high-molecular-weight polyethylene (UHMWPE) on CoCrMo, the lowest wear was obtained in pure water while the wear rate increased with the addition of bovine serum [20,21]. In agreement with McNulty, a further increase of the protein concentration led to lower wear again [19-21]. Schwenke et al. obtained five times higher wear comparing two test liquids, but it is not clear whether this was an effect of the different protein concentrations $(30 \mathrm{~g} / \mathrm{L} v \mathrm{~s} .19 \mathrm{~g} / \mathrm{L})$ or of the additives (ethylenediaminetetraacetic acid disodium salt dihydrate (EDTA) and antimycotics Patricin A vs. propylene phenoxetol and tris) [22]. The type and the composition of the serum play an important role, as shown by different authors [23-25]. Testing different proteins showed that they have different lubricating properties [26,27].

Compared to the existing test liquids, the composition of the synovial fluid is more complex, as it contains water, hyaluronic acid (HA), proteins (albumin, immunoglobulins, AGP, A1AT etc.), salts, enzymes, lipids, and cells of the joint capsule and components of the immune system. Its composition varies between individuals and between healthy joints and arthritic or diseased joints [7-10,27,28]. The healthy synovial fluid contains about $20 \mathrm{~g} / \mathrm{L}$ of proteins (ranges between 5 and $38 \mathrm{~g} / \mathrm{L}$ ). The protein concentration often is elevated in diseased joints with a mean value of around $30 \mathrm{~g} / \mathrm{L}$, but top values of up to $60 \mathrm{~g} / \mathrm{L}$ have been reported [29]. This is because in diseased joints the permeability 
of the synovial membrane for the plasma proteins is increased. Additionally, the ratio of the dominant proteins albumin and gamma globulins changes; while in healthy joints, the albumin/globulin ratio is in the range of 1.6:1-1.8:1 [30,31], diseases might either cause a reduction of the ratio down to $1: 1$ or even less [29] or an increase of the ratio above 2:1 [32]. The majority of glycosaminoglycans in the synovial fluid is HA, only $2 \%$ is chondroitin sulphate [33]. The concentration of HA in the synovial fluid is in the range of $2 \%-3 \%$ with molecular weights of $10^{6}-10^{7} \mathrm{Da}[29,31,33,34]$. The concentration of the HA in diseased joints can drop to $0.3 \%-1.8 \%$ with molecular weights of $1-2 \times 10^{6} \mathrm{Da}[29,33]$. Although the concentration is diminished, the total mass per joint might be higher, as the volume of the synovial fluid increases. The decreased molecular weight is thought to be rather due to a defect in polymerization than to degradation [34-36]. In addition to the main HA/protein mixture, the synovial fluid contains salts (such as calcium, chloride, potassium and sodium) in concentrations lower than in the serum (Ca: 1.2-2.4, Cl: 87-138, K: 3.5-3.5 and Na: 133-139 mmol/L) [31,33].

As there are only a few millilitres present in healthy joints [29,33], there is not enough synovial fluid available to perform hip simulator tests, where litres of test liquids are needed. Nevertheless, pin-on-disc experiments have been performed with synovial fluids. Lee et al. showed on mica sheets that, with a higher HA molecular weight, the friction increased while the wear decreased [37].

There are many different approaches to mimic the synovial fluid, most of them based on HA [25,28,35,38,39], carboxy methyl cellulose [40-42], polyvinylpyrrolidone [43] or polysaccharides (sodium alginate and gellan gum) [44,45] together a with single type of protein or with proteins from bovine serum. With these substances, the viscosity could be increased to values similar as in the synovial fluid [35,39,41,43-45]. Lubrication with synovial fluid usually results in lower friction than with artificial test liquids based on bovine serum albumin (BSA) [18,46] or bovine serum [40,47]. Other studies report even lower friction with HA in saline [46] while similar friction coefficients were obtained with a highly viscous test liquid containing carboxy methyl cellulose [41]. However, using a lubricant containing sodium alginate and gellan gum but no proteins, Thompson et al. found unrealistically low wear factors and a polyethylene transfer film, which is not typical for hip implants [45].

The aim of this study was to mimic the genuine synovial fluid by using HA and the most abundant proteins present in the synovial fluid, and this at reasonable costs. This permits one to overcome the problems of comparability and reproducibility and to find an ideal way to simulate the in vivo lubrication and thus to be able to predict the in vivo wear performance of joint prostheses. Different test liquids were prepared and their influence on the viscosity, the friction coefficient, the wear rate and the wear debris of UHMWPE pins in articulation with CoCrMo discs was investigated. The material pairing of UHMWPE on CoCrMo had been chosen, because it is the most often used in hip and knee prostheses and numerous in vivo and in vitro data is available for this material pairing.

\section{Materials and Methods}

\subsection{Test Liquids}

Six test liquids were prepared changing only one parameter at a time (Table 1). As a reference, a hip simulator test liquid according to ISO 14242-1:2014 was used (HiSi-mix). This consisted of NCS from 
New Zealand (Thermo Fisher Scientific, Waltham, MA, USA, Lot 8097790, 64 g/L protein concentration), diluted with deionized water to a protein concentration of $30 \mathrm{~g} / \mathrm{L}$. Sodium azide and EDTA were added ( $2 \mathrm{~g} / \mathrm{L}$ and $3 \mathrm{~g} / \mathrm{L}$ respectively; both p.a., Sigma-Aldrich Chemie GmbH, Steinheim, Germany) to inhibit bacterial growth and to bind metallic ions. The HiSi-mix with the same lot of NCS was used for hip simulator studies, showing reasonable wear rates that were comparable to in vivo data. The second test liquid contained a concentration of $3 \mathrm{~g} / \mathrm{L}$ HA (technical; pure bulk Inc., Roseburg, OR, USA, Mw $=1.3 \times 10^{6} \mathrm{Da}$ ) in addition to the diluted NCS. Next, the deionized water was replaced by Ringer solution (RS, Laboratorium Dr. G. Bichsel AG, Unterseen, Switzerland). In a further step, the NCS was substituted by lyophilized proteins: First, only BSA (Bioclot GmbH, Aidenbach, Germany) with a concentration of $30 \mathrm{~g} / \mathrm{L}$ was used as substituent, later, a mixture of $19 \mathrm{~g} / \mathrm{L} \mathrm{BSA}$ and $11 \mathrm{~g} / \mathrm{L}$ immunoglobulin G (IgG, bioWORLD, division of GeneLinx International, Inc., Dublin, OH, USA) was used. In the final step, the phospholipid lecithin (PL, pure bulk Inc.) with a concentration of $0.1 \mathrm{~g} / \mathrm{L}$ was added.

Table 1. Composition (g/L) of the individual test liquids (HiSi-mix: standard hip simulator mix).

\begin{tabular}{|c|c|c|c|c|c|c|c|}
\hline \multirow{3}{*}{ Test Liquid } & \multicolumn{7}{|c|}{ Components (g/L) } \\
\hline & HA & NCS & BSA & IgG & PL & Deionized & RS \\
\hline & Hyaluronic Acid & $\begin{array}{c}\text { Newborn Calf } \\
\text { Serum }\end{array}$ & $\begin{array}{l}\text { Bov. Serum } \\
\text { Albumin }\end{array}$ & Immuno-Globulin G & $\begin{array}{c}\text { Phospho-Lipid } \\
\text { Lecithin }\end{array}$ & Water & Ringer Solution \\
\hline HiSi-mix & & 30 & & & & balance & \\
\hline HA NCS & 3 & 30 & & & & balance & \\
\hline HA NCS RS & 3 & 30 & & & & & balance \\
\hline HA BSA RS & 3 & & 30 & & & & balance \\
\hline HA BSA/IgG RS & 3 & & 19 & 11 & & & balance \\
\hline HA BSA/IgG PL RS & 3 & & 19 & 11 & 0.1 & & balance \\
\hline
\end{tabular}

The test liquids were prepared in a clean-room. They were stored at $4{ }^{\circ} \mathrm{C}$ and used within $48 \mathrm{~h}$ after preparation or kept frozen if used at a later time point. Powders were weighed on a balance with an accuracy of $0.01 \mathrm{mg}$ (Mettler Toledo Intl., Columbus, OH, USA, AX205) and volumes were quantified with Eppendorf pipettes (Eppendorf, Hamburg, Germany).

\subsection{Viscosity Measurements}

The viscosity of the test liquids was analysed using a rotational viscometer with Couette geometry (Anton Paar, Graz, Austria, MCR 300). The bob (radius $14.254 \mathrm{~mm}$, length $46.92 \mathrm{~mm}$ ) was rotated inside the cup (inner radius $14.462 \mathrm{~mm}$ ) with different velocities, thus the liquid film of a thickness of $0.208 \mathrm{~mm}$ was sheared at different rates. By measuring the torque, the viscosity $\eta$ was calculated. The test protocol consisted of three intervals: first, the shear rate was stepwise increased from $0.1 \mathrm{~Hz}$ up to $1000 \mathrm{~Hz}$, followed by the second two minutes interval with a constant shear rate of $1000 \mathrm{~Hz}$ and the third interval with decreasing shear rates from $1000 \mathrm{~Hz}$ back to $0.1 \mathrm{~Hz}$. The upper limit was chosen to minimize measurement errors due to turbulences in the analyte, preferential orientation or degradation of proteins and/or HA polymeric chains. The time between two different shear rates was $12 \mathrm{~s}$ and the data for one measuring point were the average and the standard deviation of the last two seconds of these intervals. 


\subsection{Tribological Testing}

For the tribological tests, UHMWPE (GUR 1020, Ticona, Florence, KY, USA, according to ISO 5834-1 and -2) were turned to pins of a diameter of $9.52 \mathrm{~mm}$ and a length of $20 \mathrm{~mm}$ (RMS Foundation, Bettlach, Switzerland). The roughness of the pins and discs was determined with confocal microscopy (details in Section 2.6.2). The mean arithmetic roughness $R_{a}$ on the end plane was $0.4 \pm 0.1 \mu \mathrm{m}$. The end of the pins used for the friction measurements was turned to a radius of $36 \mathrm{~mm}$ (Stalder Startech $\mathrm{GmbH}$, Bettlach, Switzerland, $\mathrm{R}_{\mathrm{a}}=1.5 \pm 0.2 \mu \mathrm{m}$ ) in order to maintain higher contact pressures and to avoid artefacts due to edges. Prior to testing, the pins were packed under nitrogen (Früh Verpackungstechnik AG, Fehraltorf, Switzerland) and were gamma irradiated with 30 kGy (Leoni Studer AG, Däniken, Switzerland) according to the guidelines for sterilization of polymeric implant devices.

The counterface discs used for the friction and wear tests were made of a wrought low carbon CoCrMo alloy used for implants (according to ISO 5832-12). They were ground and subsequently polished with nine, six and $3 \mu \mathrm{m}$ diamond paste on a polishing machine (Struers GmbH, Willich, Germany). The final polishing step was performed with an acidic alumina suspension (OP-A suspension, Struers $\mathrm{GmbH}$ ), resulting in a mean arithmetic roughness $R_{a}$ of $7 \pm 3 \mathrm{~nm}$.

\subsection{Friction Measurements}

The friction was measured on a reciprocal pin-on-disc tribometer (Figure 1), developed in cooperation with the Bern University of Applied Sciences, Switzerland [48]. The curved UHMWPE pin was screwed onto the movable measuring block on top, which then was attached to the frame of the tribometer by two vertical springs. The normal force was adjusted to $1 \mathrm{~N}$ via precision screws adjusting the elongation of the two springs. The counterpart beneath was a polished CoCrMo disc placed in a stainless steel vessel. The vessel was filled with about $10 \mathrm{~mL}$ test liquid and was mounted on a reciprocal drive allowing sliding speeds in the range of $1-20 \mathrm{~mm} / \mathrm{s}$. The friction forces were measured on the upper measuring block which was laterally clamped by four parallel arranged ceramic beam force sensors which were preloaded with $150-175 \mathrm{mN}$. The forces were calibrated using test weights and the accuracy was better than $1 \%$. The control of the linear motor and the data acquisition (sampling rate $100 \mathrm{~Hz}$ ) was done with Labview software (national instruments corporation, Austin, TX, USA).

Prior to each experiment, a running-in was performed at a sliding speed of $10 \mathrm{~mm} / \mathrm{s}$ for $3 \mathrm{~h}$ (Figure 2). The main experiment consisted of intervals of $30 \mathrm{~min}$ with increasing sliding speeds ranging from 1-20 mm/s (1, 2, 4, 7, 12 and $20 \mathrm{~mm} / \mathrm{s})$. The sliding distance was $10 \mathrm{~mm}$. The applied load of $1 \mathrm{~N}$ led to a contact pressure of about $5 \mathrm{MPa}$. The test liquids were freshly prepared for each test, but not renewed during a test. All friction measurements were performed at room temperature $\left(21 \pm 1{ }^{\circ} \mathrm{C}\right)$ in a clean room. Each experiment was done in triplicate.

The software Octave was used for the data processing (gnu.org, version 3.6.2, operated with GUI Octave 1.7.0). The procedure imported the raw-data generated by the tribometer, i.e., friction force, normal force, time and sliding speed. Because of small vibrations of the measuring block with a frequency of about $20 \mathrm{~Hz}$, a triangular smoothing with $\mathrm{m}=7$ was applied (covering $60 \mathrm{~ms}$ ). Since the 
sliding speed was not constant at the endpoints of the reciprocal motion, only the friction coefficients obtained at the central $5 \mathrm{~mm}$ were taken into account. The reported values are the averages \pm the standard deviations of the three samples over the last $25 \mathrm{~min}$ of the $30 \mathrm{~min}$ at each sliding speed.

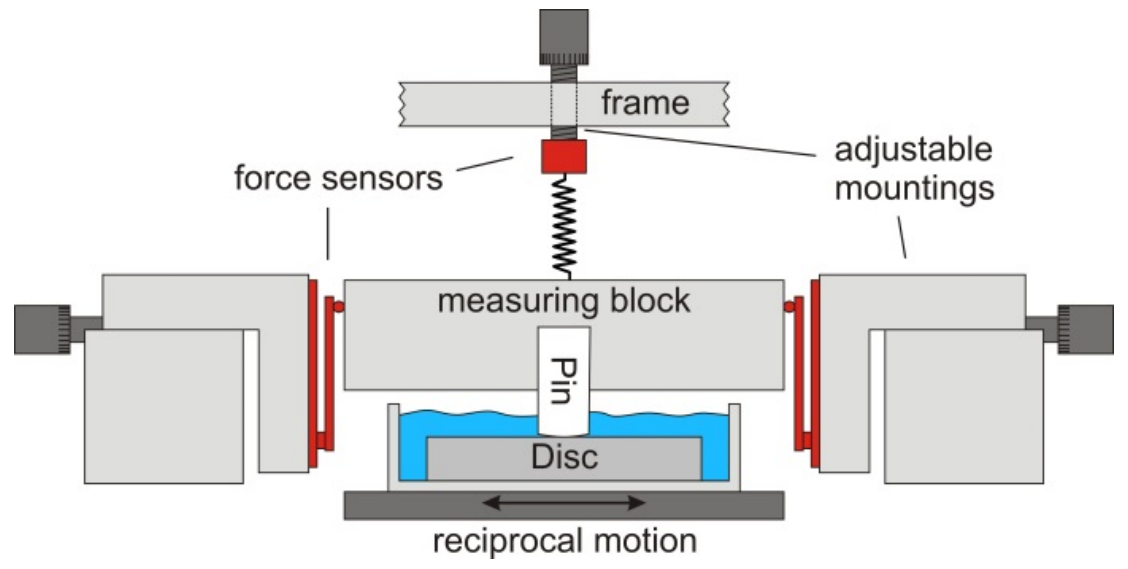

Figure 1. Schematic drawing of the reciprocal pin-on-disc tribometer. The measuring block is mounted on two adjustable springs, which allow for adjusting the required load. Underneath, the disc immersed in the test liquid is moved reciprocally while the friction force is measured by two force sensors placed on both sides of the measuring block.

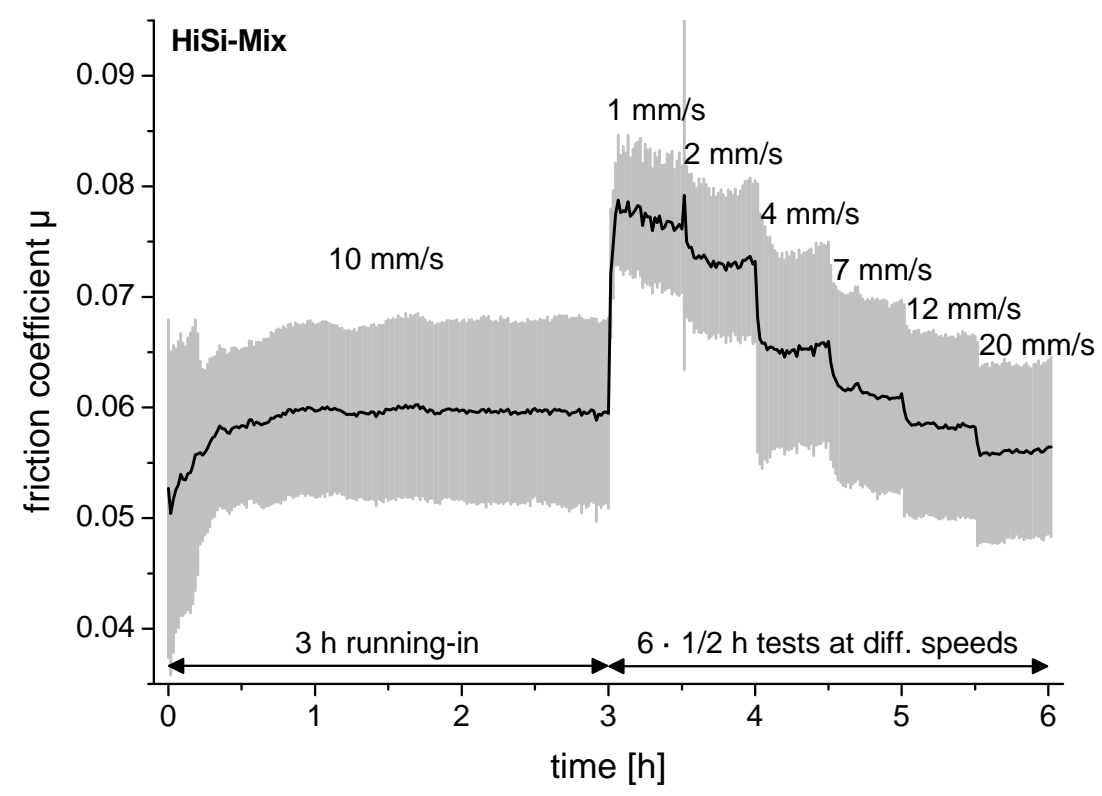

Figure 2. Friction coefficient of an experiment demonstrating the test protocol with $3 \mathrm{~h}$ running-in prior to the tests at different sliding speeds. The black line is the average per minute and the grey lines are the standard deviations. The test liquid used in this experiment was the standard hip-simulator test liquid (HiSi-mix).

\subsection{Wear Tests}

The wear resistance of flat UHMWPE pins articulating against CoCrMo discs was tested on a six-station, bidirectional pin-on-disc device (AMTI, Watertown, MA, USA, OrthoPOD). The pins ( $n=3$ for each test liquid) and the discs were immersed in $10 \mathrm{~mL}$ of the test liquids, which were kept 
at $37 \pm 1{ }^{\circ} \mathrm{C}$. To minimize bio-deterioration due to bacteria during the long-term wear measurements, silver-coated copper wires were inserted into the test chambers. They corroded there and thus released copper and silver ions - which have an antimicrobial effect - into the test liquid. The motion profile consisted of a rectangular motion path $(10 \mathrm{~mm} \times 5 \mathrm{~mm})$ with varying applied peak loads of $250 \mathrm{~N}-10 \mathrm{~N}-125 \mathrm{~N}-10 \mathrm{~N}$ at the corners (3.5 MPa maximum contact pressure). The cycles lasted $1 \mathrm{~s}$ and were repeated continuously. Each test was carried out for 2 million cycles with sample weighing at $0.25,0.5,1,1.5$ and 2 million cycles. To compensate for the soaking, one pin was exposed to the same test liquid and heated to $37 \pm 1{ }^{\circ} \mathrm{C}$ but was neither exposed to load nor to motion.

Before weighing, the pins were cleaned in an ultrasonic bath for $10 \mathrm{~min}$, first with cleaning detergent (Borer Chemie AG, Zuchwil, Switzerland, deconex 12 PA) and afterwards twice in deionized water. After rinsing with isopropanol, they were stabilized for one hour in an exsiccator (relative humidity 49\%). Weighing was repeated once and the average of the two measurements was taken. If the two measurements for one pin differed by more than $0.03 \mathrm{mg}$, all pins were measured again corresponding to the protocol suggested in ISO 14242-2 [49]. After weighing, the test chambers with the pins and discs were reassembled and filled with fresh test liquid for further testing. Wear was determined by measuring the weight loss of the pins during the tests, corrected with the weight gain due to soaking. The wear rates were determined applying linear fits through the corrected weights of the pins without taking the zero-time point into account (according to ISO 14242-2 [49]).

\subsection{Sample Characterisation}

\subsubsection{Proteins}

The presence of salts in the lyophilized proteins BSA and IgG was investigated using X-ray photoelectron spectroscopy (XPS, Kratos Analytical, Manchester, UK, Axis Nova) as this information was not provided in their datasheets. Photoelectrons were generated with monochromatic AlK $\alpha$-irradiation (225 W). Charging of the samples was overcompensated with a charge neutralizer using slow electrons. The photoelectrons were detected with a hemispherical analyser operated at $40 \mathrm{eV}$ pass energy for the detailed spectra and $80 \mathrm{eV}$ pass energy for the survey spectra (full-width at half maximum of $\mathrm{Ag} 3 \mathrm{~d}_{5 / 2}$ of 0.6 and $0.9 \mathrm{eV}$ respectively). The data processing was performed using CasaXPS software (Casa Software Ltd, Teignmouth, UK, version 2.3.15). Charging was corrected by referencing the binding energy of aliphatic carbon to $285 \mathrm{eV}$ [50]. Besides carbon, oxygen and nitrogen from the peptides, BSA contained $0.8 \pm 0.1 \mathrm{wt} \%$ phosphorus and sulphur together with $0.3 \mathrm{wt} \%$ sodium. In the case of IgG $0.7 \pm 0.1 \mathrm{wt} \%$ sulphur, $4 \pm 1 \mathrm{wt} \%$ sodium, traces of magnesium and $6 \pm 2 \mathrm{wt} \%$ chlorine were detected. The binding energy of $\mathrm{P} 2 \mathrm{p}_{3 / 2}$ was at $133.2 \pm 0.1 \mathrm{eV}$ indicating that phosphorus was present as phosphate [51]. Sulphur $2 \mathrm{p}_{3 / 2}$ at $163.7 \pm 0.1 \mathrm{eV}$ could be from elemental sulphur or sulphides [51]. Chlorine at $198.8 \pm 0.2 \mathrm{eV}$ originates from chlorides [51].

\subsubsection{Surface Characterisation}

The surface of the pins was documented by light microscopy (Leica Microsystems GmbH, Wetzlar, Germany, Leica DMI 5000M) and scanning electron microscopy (SEM; Carl Zeiss AG, Jena, Germany, EVO MA25). The topography of the pins and discs was investigated using a confocal 
microscope with a 20X object lens (NanoFocus AG, Oberhausen, Germany, $\mu$ Surf, data processing with $\mu$ Soft analysis XT, V6.2.6122). Topographies were flattened by a plane (excluding the areas containing elevations). Roughness values were determined according to ISO 4287 and 4288 after extracting more than ten profiles from the topographies.

\subsubsection{Particle Analysis}

The morphology of the wear particles was determined using SEM. $5 \mathrm{~mL}$ of the test liquids collected after 1.5 million cycles of the wear tests were diluted with $40 \mathrm{~mL}$ of hydrochloric acid (37\%, p.a., Merck KGaA, Darmstadt, Germany) and heated in a water bath to $50{ }^{\circ} \mathrm{C}$ for three hours to dissolve the proteins. After cooling, $1 \mathrm{~mL}$ of this solution was diluted with $100 \mathrm{~mL}$ methanol (Merck KGaA, SeccoSolv) and filtered using a $0.05 \mu \mathrm{m}$ filter (Merck KGaA, millipore). All utilized equipment was rinsed with $0.2 \mu \mathrm{m}$ filtered, deionized water prior to usage in order to minimize the risk of contamination of the samples by dust or other particles. Prior to the examination using SEM, the filters were dried in an exsiccator and sputter-coated with gold (Leica Microsystems GmbH, Wetzlar, Germany, Bal-Tec SCD 050).

The size of the particles was measured using a laser diffractometer (Beckman Coulter Inc., Brea/Indianapolis, IN, USA, LS 13320). A slightly different digestion protocol was applied: Prior to the digestion process, the test liquid was sonicated for $15 \mathrm{~min}$ and let under magnetic stirring for another $15 \mathrm{~min}$. Hydrochloric acid was added to the liquid sample (ratio 5:1) and heated to $60{ }^{\circ} \mathrm{C}$ for $55 \mathrm{~min}$ under magnetic stirring (400 rpm). An aliquot of $1 \mathrm{~mL}$ was diluted in $100 \mathrm{~mL}$ absolute ethanol. $0.45 \mathrm{~mL}$ of the resulting solution were analysed with the laser diffractometer. The measurement was repeated three times to reduce the risk of measuring artefacts (e.g., air bubbles). The data were processed applying the Mie diffraction model.

\subsection{Statistics}

The values are reported as average \pm standard deviations. Statistical testing was performed applying an independent two-sided Student's $t$-test with unequal variances if not further specified.

\section{Results}

\subsection{Viscosity}

A viscosity of $0.94 \pm 0.03 \mathrm{mPas}$ was measured for the HiSi-mix at all shear rates (Figure 3 ). This was close to the viscosity of water $(0.86 \pm 0.03 \mathrm{mPas})$, which was used as a reference. By adding $3 \mathrm{~g} / \mathrm{L}$ hyaluronic acid, the viscosity increased to $12-65 \mathrm{mPas}$. A shear thinning was observed, meaning that the viscosity decreased with increasing shear rates. The viscosity decreased slightly after salts were added by using RS instead of water to dilute the serum (HA NCS RS vs. HA NCS). Substituting the newborn calf serum by defined proteins led to a further slight decrease of the viscosity. 


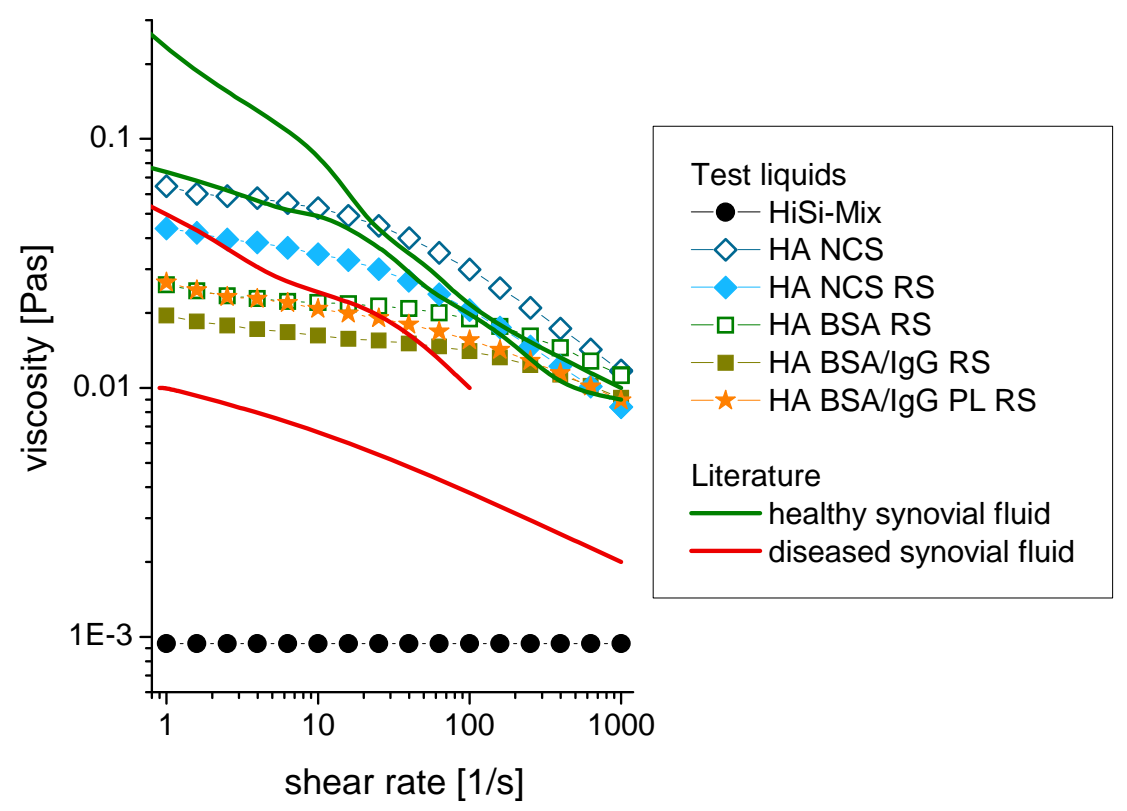

Figure 3. Shear rate dependence of the viscosity of different test liquids and comparison to the literature $[34,36]$. The standard deviation of the measurements was smaller than the size of the symbols. Abbreviations: HiSi-mix: Hip simulator test liquid according to ISO 14242-1, HA: hyaluronic acid, NCS: newborn calf serum, RS: Ringer solution, BSA: bovine serum albumin, IgG: immunoglobulin G, PL: phospholipid (lecithin in this study).

\subsection{Friction}

The friction coefficients are presented in a Stribeck plot [52] with the Sommerfeld number on the $\mathrm{x}$-axis (Figure 4). The Sommerfeld number is defined as the product of the viscosity and the sliding speed divided by the applied load. All friction coefficients were between 0.045 and 0.09 . The highest friction was obtained for the HiSi-mix at low speeds. With increasing sliding speeds, the friction coefficients decreased (two-sided, paired Student's $t$-test: $p<0.001$, except for sliding speed of $7 \mathrm{~mm} / \mathrm{s}$ vs. $4 \mathrm{~mm} / \mathrm{s}: p=0.8$ ), where the decrease was most pronounced for the HiSi-mix. The addition of HA led to a decrease of the friction coefficient compared to the HiSi-mix $(p=0.0002)$, while the addition of the salts did not affect friction $(p=0.4)$. The lowest friction was measured at high sliding speeds using the test liquids containing HA and NCS. Replacing the NCS with single proteins led to a slight increase at slow sliding speeds $(p=0.01)$. Large variations between the individual repetitions of the experiments were observed for the test liquids HA NCS, HA BSA RS and HA BSA/IgG RS, leading to high standard deviations. A higher reproducibility was obtained with the test liquids HiSi-mix, HA NCS RS and HA BSA/IgG PL RS. The latter showed a smaller sliding speed dependency but similar friction coefficients as the HiSi-mix at high sliding speeds. 


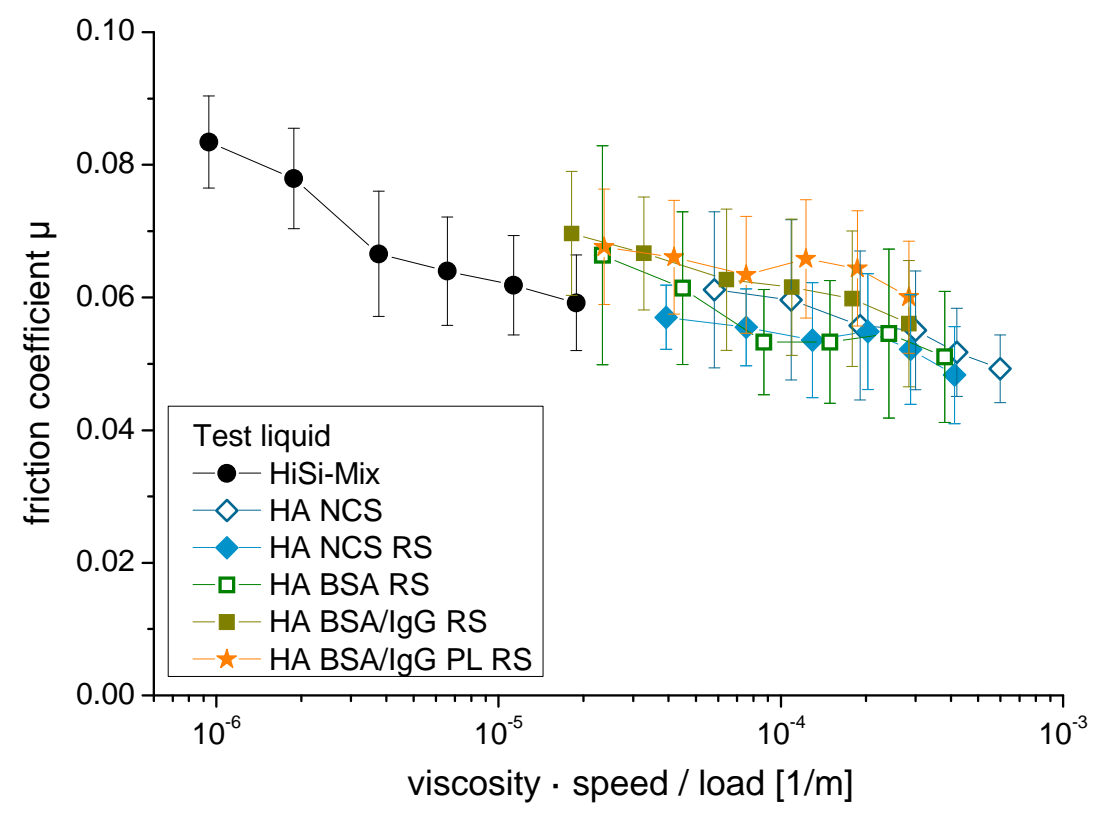

Figure 4. Stribeck plot with the friction coefficients of ultra-high-molecular-weight (UHMWPE) pins vs. CoCrMo discs lubricated with different test liquids. The sliding speeds varied between 1 and $20 \mathrm{~mm} / \mathrm{s}$.

\subsection{Gravimetric Wear}

The weight loss of the UHMWPE pins steadily increased with the performed cycles (Figure 5). The average wear rates were between $5.5 \pm 0.6$ and $10.7 \pm 0.4 \mathrm{mg} / \mathrm{million}$ cycles (Table 2$)$. The lowest wear rates were obtained with BSA as the only protein $(p<0.01)$, followed by HA NCS $(p<0.05)$. The wear rates were higher using the other test liquids, while there were no significant differences among these $(p>0.05)$ except for HA NCS RS vs. HA BSA/IgG PL RS with $p=0.03$. For a comparison with other studies, the wear coefficient $k$ is given in Table 2. This is the volumetric wear rate taking into account the polyethylene density of $936 \mathrm{~kg} / \mathrm{m}^{3}$ [53] and being normalized with the applied load-distance curve.

Table 2. Wear rate and wear coefficient of ultra-high-molecular-weight polyethylene (UHMWPE) pins sliding on CoCrMo discs in different test liquids.

\begin{tabular}{lcc}
\hline Test Liquid & Wear Rate $\mathbf{( m g / m i l l i o n ~ C y c l e s )}$ & Wear Coefficient $\left(\mathbf{m m}^{\mathbf{3}} \mathbf{\mathbf { N m } )}\right.$ \\
\hline HiSi-mix & $8.2 \pm 0.9$ & $3.0 \pm 0.3 \times 10^{-6}$ \\
HA NCS & $6.8 \pm 0.1$ & $2.4 \pm 0.1 \times 10^{-6}$ \\
HA NCS RS & $9.0 \pm 0.7$ & $3.3 \pm 0.2 \times 10^{-6}$ \\
\hline HA BSA RS & $5.5 \pm 0.6$ & $2.0 \pm 0.2 \times 10^{-6}$ \\
HA BSA/IgG RS & $10.0 \pm 0.6$ & $3.6 \pm 0.2 \times 10^{-6}$ \\
HA BSA/IgG PL RS & $10.7 \pm 0.4$ & $3.9 \pm 0.2 \times 10^{-6}$ \\
\hline
\end{tabular}




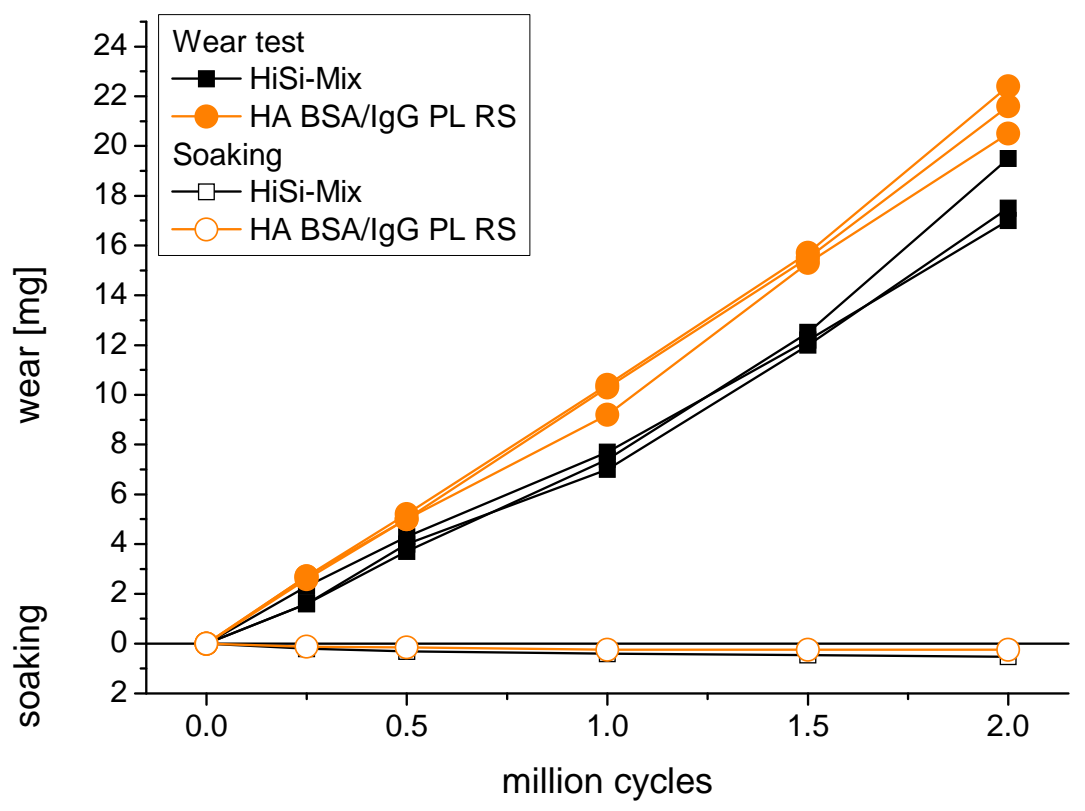

Figure 5. Wear of UHMWPE pins sliding against CoCrMo discs in the HiSi-mix and in the test liquid containing hyaluronic acid, bovine serum albumin, immunoglobulin $\mathrm{G}$, the phospholipid lecithin and ringer solution (HA BSA/IgG PL RS). The soaking of non-loaded reference pins was determined to compensate for the uptake of test liquid.

\subsection{Surface Characterisation}

The toolmarks on the pins from the machining were removed during the wear tests (Figure 6a). Some scratches were observed both on the pins and the discs (Figure 6e). On the latter, they often had a rectangular shape corresponding to the performed track. While the roughness of the disc was not affected by the wear test, the roughness of the pins was reduced from $\mathrm{Ra}=0.4 \pm 0.1 \mu \mathrm{m}$ before the test to $0.10 \pm 0.05 \mu \mathrm{m}$ after the test. Additionally, the pins exhibited features that looked like pitting. Investigating these features using confocal microscopy showed that they were in fact elevations (Figure 6c,d) composed of small particles (Figure 6f,g).

\subsection{Wear Debris}

Wear debris was analysed by SEM (Figure 7). The most abundant particles were small granular particles in the sub-micron range together with fibrils in various lengths. The granular particles sometimes formed larger agglomerates. A multimodal size distribution was observed with laser diffraction, centred at $0.07,0.3$ and $2 \mu \mathrm{m}$ by volume and at $0.06 \mu \mathrm{m}$ by number (Figure 8 ). No difference in the size distributions of wear particles obtained with the different test liquids was observed. 


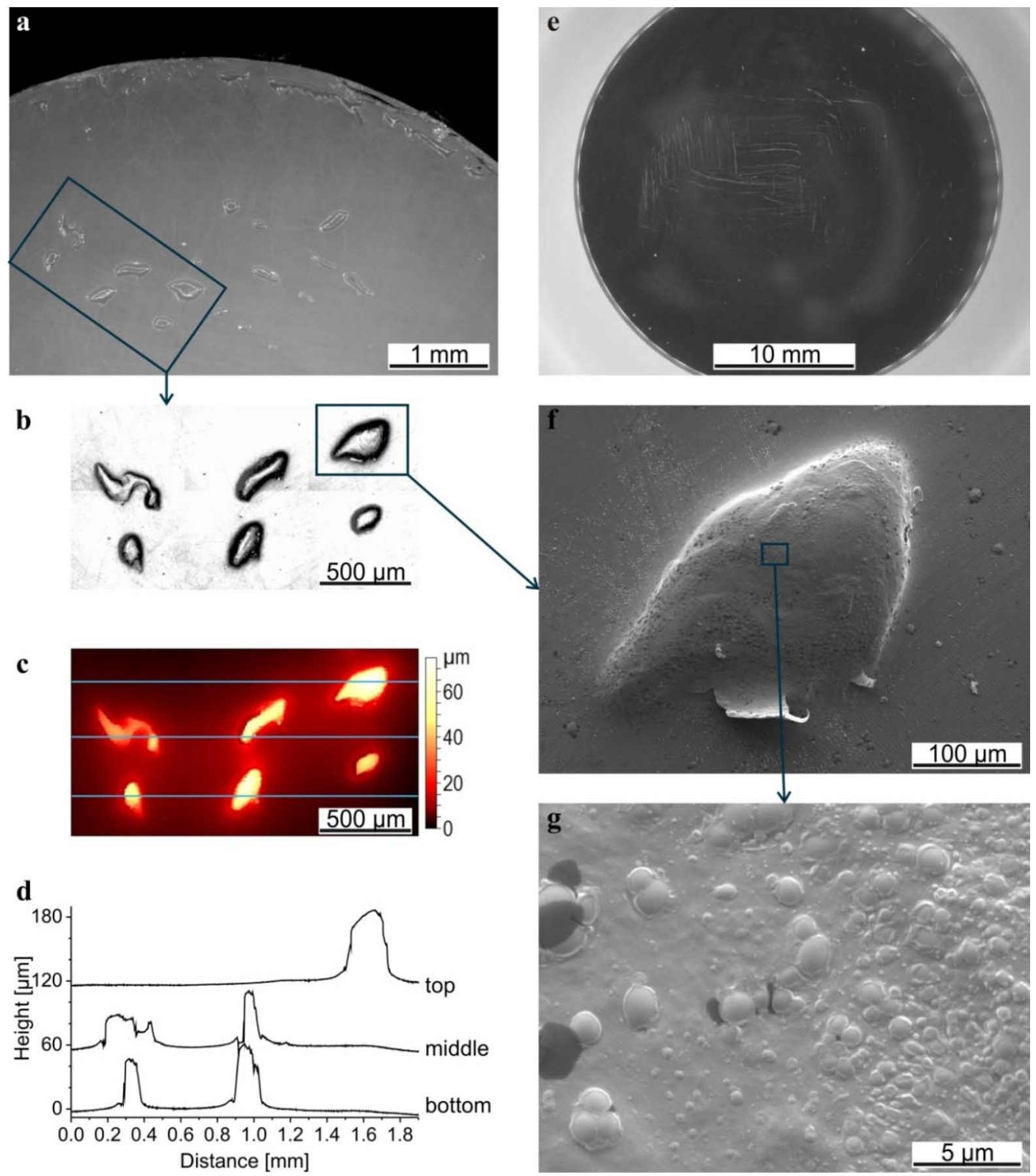

Figure 6. Microscopy images of a pin (a) and disc (e) after the wear test in HA BSA/IgG PL RS; (b) Intensity of the confocal image of the marked rectangle in (a) and (c) the corresponding topography; (d) Profiles extracted from the topography, crossing the elevations on the top, in the middle and on the bottom (positions indicated with blue lines). The profiles were shifted by 60 and $120 \mu \mathrm{m}$ for a better overview; (f) Scanning electron microscope (SEM) image of the elevation marked in (b) and of the structure on the top of that elevation $(\mathbf{g})$. 


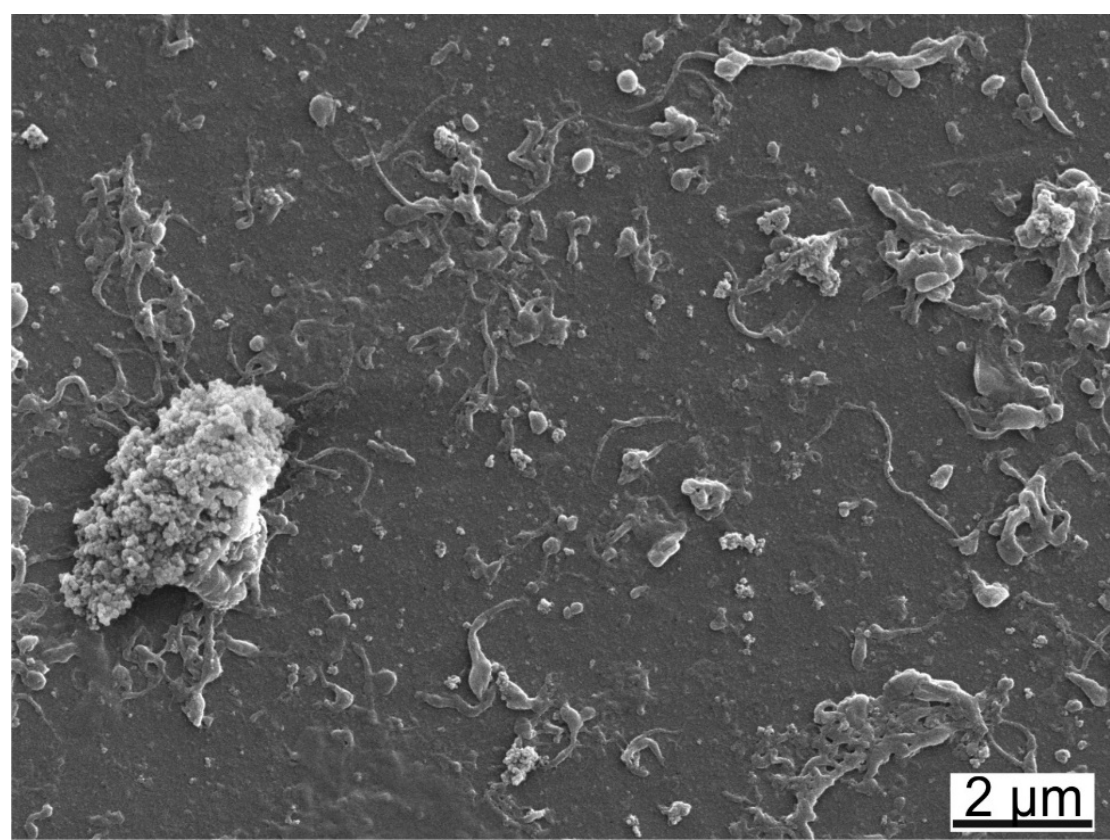

Figure 7. SEM-image of wear particles collected after the wear test lubricated with HA BSA/IgG PL RS showing round particles, fibrils and agglomerates.
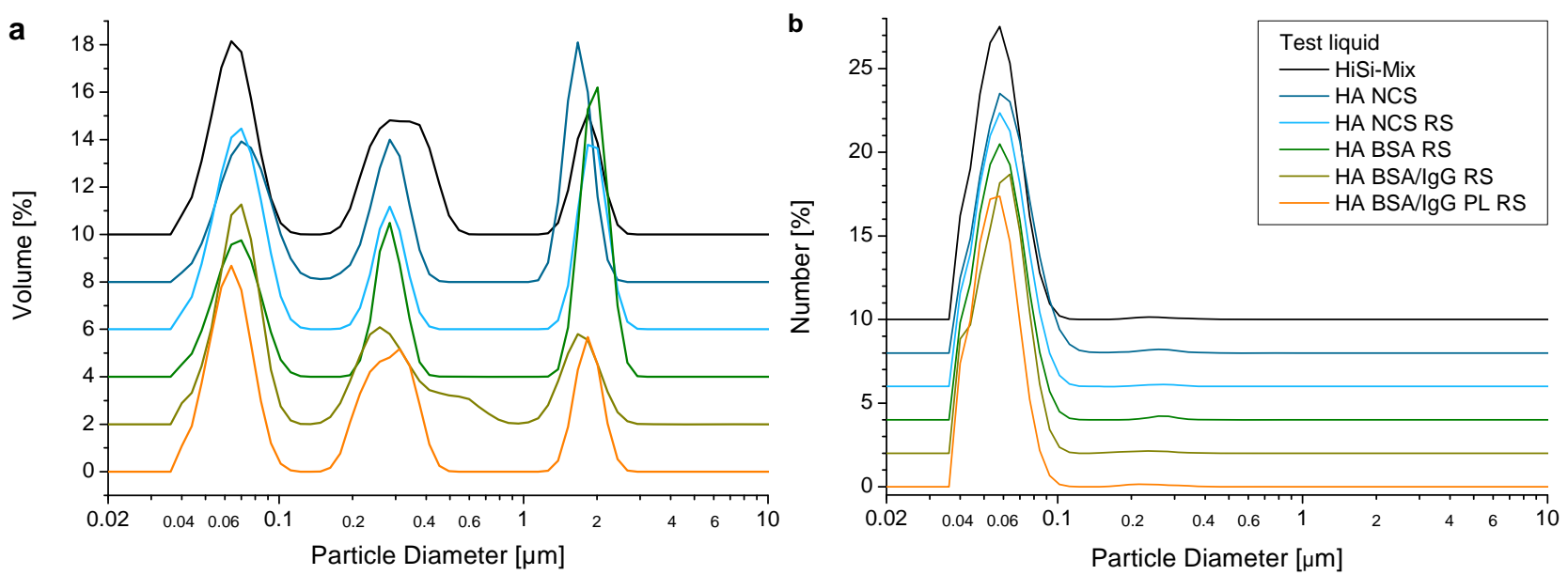

Figure 8. Diameter of wear particles ((a) by volume, (b) by number) determined with laser diffraction. For a better overview, the curves were shifted by a multiple of $2 \%$.

\section{Discussion}

\subsection{Constituents and Their Concentrations}

Based on the composition of the genuine synovial fluid, the composition of the test liquids were changed step-by-step from the HiSi-mix according to ISO 14242-1 to a synthetic synovial fluid composed of the pure substances HA, BSA, IgG, PL and RS (Table 1). The concentration of HA was determined in pre-experiments [54] in order to reach the required viscosities found in human synovial fluids $[34,36,41,55,56]$. The total protein concentration of $30 \mathrm{~g} / \mathrm{L}$ corresponds to the ISO 14242-1:2014 standard and to an average protein concentration found in patients with osteoarthritis [8-10,28]. BSA and $\operatorname{IgG}$ were chosen because they are the most prominent proteins in the synovial fluid and available 
in large quantities. The ratio of 1.7:1 corresponds to the ratio found in synovial fluids [30,31]. The phospholipid lecithin was added since phospholipids are supposed to act as boundary lubricants [57].

\subsection{Viscosity}

Increasing the concentration of HA highly increases the viscosity [54]. The viscosities of test liquids containing $3 \mathrm{~g} / \mathrm{L}$ HA were within the values for genuine synovial fluids from healthy joints (Figure 3: green curves) and from rheumatoid joints (red curves) [34,36]. The HA used in this study had a molecular weight of $1.3 \times 10^{6} \mathrm{Da}$, which is comparable to HA in diseased joints [8]. HA builds hydrogen bonds both with water and with other HA molecules. With more and longer HA chains, more entanglements are formed and thus both higher concentrations and higher molecular weights lead to a viscosity increase. Former studies showed that the viscous behaviour of the synovial fluid was mainly determined by the presence of HA [34-36,56].

Adding RS to the test liquids caused a slight decrease of the viscosity. By adding RS, salts and herewith ions were added to the test liquid. This led to an electrical screening of dissociated acid groups over a shorter distance. Thus, less hydrogen bonds were formed and therefore the bonding forces between the HA chains were diminished, resulting in a decrease of the viscosity.

Substituting NCS by single proteins led to a further reduction of the viscosity. The total amount of the proteins was constant and the main proteins were the same, thus a limited effect on the viscosity by the proteins was expected. Because the datasheet of the proteins did not contain information about the salt content, it was determined with XPS (see Section 2.6.1). It was found that BSA contained about $2 \mathrm{wt} \%$ of ionic elements (sodium, phosphorus and sulphur) while IgG even contained $10 \mathrm{wt} \%$ ionic elements, which was mainly sodium chloride. This led to an additional salt content of $0.6 \mathrm{wt} \%$ for BSA and of $1.5 \mathrm{wt} \%$ for $\mathrm{BSA} / \mathrm{IgG}$ in the test liquids. Therefore, an enhanced neutralisation of the dissociated acid groups of the HA took place, which explains the further decrease of the viscosity.

\subsection{Friction and Wear}

The friction tests were performed at sliding speeds ranging from 1-20 mm/s. The slow sliding speeds represent the situation in a hip prosthesis of a slowly walking person while the higher sliding speeds are present at fast walking. The resulting friction coefficients were similar as found in studies for UHMWPE sliding on CoCrMo lubricated with rheumatoid synovial fluids $(0.04-0.06$ [41,58]). The obtained wear coefficients of $2-4 \times 10^{-6} \mathrm{~mm}^{3} / \mathrm{Nm}$ were in the same range as clinically observed wear with an average of $0.137 \mathrm{~mm} /$ year and a range from $0.02 \pm 0.02$ to $0.27 \pm 0.01 \mathrm{~mm} /$ year, depending on the individual study reviewed by Kurtz et al. [59]. This corresponds approximately to a wear factor of $1.4 \times 10^{-6} \mathrm{~mm}^{3} / \mathrm{Nm}$ (range $0.2-2.8 \times 10^{-6} \mathrm{~mm}^{3} / \mathrm{Nm}$, conversion according to [60]).

Several authors draw different conclusions about whether or not HA is a necessary constituent for boundary lubrication in vivo and in vitro [40,61,62]. HA shows little adsorption on surfaces [63] and thus is unlikely to act as boundary lubricant. However, adding HA to the test liquids led to lower friction for all applied sliding speeds. This can be explained by plotting the friction coefficient vs. the Sommerfeld number (viscosity $\times$ speed/load, Figure 4) in a so-called Stribeck plot [52,64-66]. A low Sommerfeld number indicates boundary lubrication to be the dominant mechanism while at a higher number - e.g., due to higher viscosity or at higher sliding speeds - mixed lubrication takes place. In 
the boundary lubrication regime, the load is carried by the asperities of the two surfaces or by the adsorbed boundary film respectively while in the mixed lubrication a thicker liquid film is established taking over some of the load. At a much higher Sommerfeld number there is hydrodynamic lubrication, where the asperities are fully separated by the test liquid. However, hydrodynamic lubrication is unlikely the case for hard-soft-pairings of joint replacements because of the relatively low sliding speed and the high roughness of the soft component, which is typically larger than the lubricating layer [66-68]. In agreement with these theoretical considerations, all test liquids showed a decreasing friction coefficient with increasing sliding speed (i.e., a higher Sommerfeld number), changing from the boundary to the mixed lubrication regime. However, the film thickness could not have been assessed and thus it is unknown, to what extent the lubricant film thickness actually contributed to the lubrication. Another reason might be the decreasing thickness of the boundary film made of adhering proteins, as shown for a $\mathrm{CoCr}$ head sliding against glass in diluted BCS [69], which could have led to reduced friction too. The presence of HA led to lower friction and wear, which was likely because of the viscosity increase. In agreement, Guenther et al. observed a decrease in the wear of cross-linked polyethylene pins in articulation with $\mathrm{CoCr}$ discs, when HA was added to the test liquid [70]. They explain this effect with the higher osmolality and thus an increase in thermal stability of the proteins [70]. However, they performed their tests at a higher sliding speed of $64 \mathrm{~mm} / \mathrm{s}$, which led to mixed lubrication rather than boundary lubrication with fewer asperities being in contact, and thus the viscosity was presumably a less important factor for their tests.

Adding salts to the test liquid led to an increase of wear (HA NCS RS vs. HA NCS), probably because of the reduction of the viscosity by the additional salt, leading to more asperities being in contact. In contrast, Guenther et al. got a reduction in wear of the cross-linked polyethylene pins with the addition of salts (phosphate buffered saline) to a NCS-based test liquid, which they explain as well with higher protein stability because of the increased osmolality [70]. However, this was a test liquid without HA and at higher sliding speeds too. Therefore, it can be concluded that at lower sliding speeds and with HA in the test liquid, the changes in viscosity have a larger effect than the changes in the osmolality.

Proteins immediately adsorb on the surfaces $[63,71]$ where they form a boundary lubricating layer. Albumin denatures upon adsorption on a hydrophobic surface (UHMWPE) and forms less hydrated, high shear-strength layers, whereas globulins tend to form highly hydrated layers [27,72]. This often leads to an increase in friction [27,72]. In contrast, the type of the proteins used here had only a minor effect on the friction. Only at small sliding speeds was the friction slightly higher with pure proteins instead of the NCS. If no proteins are present to protect surfaces, polymer is transferred to the counter surface $[18,71,73,74]$ and the wear mechanism changes from abrasive wear to third-body wear because of the transferred polyethylene [73]. However, there is usually less UHMWPE-wear in water compared to serum based test liquids [20,21,73] while there is less soaking of the non-polar UHMWPE in polar water compared to higher soaking in the presence of proteins, as shown by Brandt et al. for tibial inserts [75] and by unpublished investigations with UHMWPE pins performed at the RMS Foundation. Thus, the absorption of water and proteins into the material close to the surface likely impairs its mechanical strength and thus its wear resistance.

In contrast to the friction coefficient, the type of the proteins had a major effect on the wear: the lowest wear was measured with BSA as the only protein. This was confirmed by a repetition of the 
experiment with another three pins. Wang et al. performed wear tests with test liquids (without HA) where they added BSA to NCS, obtaining BSA/IgG ratios from $0.5-4$ at a constant total protein concentration of $20 \mathrm{~g} / \mathrm{L}$ [23]. With increasing ratios, they had decreasing UHMWPE-wear [23]. Exchanging the NCS by alpha calf serum led to higher wear for BSA-rich test liquids [23], demonstrating that the type and concentration of proteins can strongly affect the resulting wear, as also found by others [22,24-26]. However, in the presence of HA, similar wear rates were obtained for the test liquids HA NCS RS and HA BSA/IgG RS. This indicates that the BSA/IgG ratios of 0.7-0.8:1 in NCS [23] for the HA NCS RS and of 1.7:1 for the HA BSA/IgG RS were similar enough to produce similar wear rates. The PL led to a higher reproducibility of the resulting friction coefficients and to slightly higher wear. Since the concentration was only $0.1 \mathrm{~g} / \mathrm{L}$, it is likely that the PL acts as a boundary lubricant. Otherwise, it would have had only a negligible effect.

\subsection{Wear Particles}

Granular particles and fibrils were produced during the wear test. The granular particles often formed agglomerates. Determining the particle size with laser diffraction results in an average particle diameter, independent of the shape of the particles; even fibrils are reduced to an average diameter. With SEM, depending on the pore size of the filter, the smallest particles might get lost during filtration. Because of these two reasons generally smaller particle size distributions are obtained using laser diffraction compared to particle analysis with SEM, where often the length of the particles is measured. Taking into account this difference in methodology, similar wear particles with similar size distributions were observed in this work as in vivo [76-79] and in vitro [74,80]. The composition of the test liquid did not significantly affect the size of the particles. Mabrey et al. showed that the size distribution depends on the location of the prosthesis [76], thus it's likely that the size rather depends on the loading and motion pattern than on the presence of HA, salts or the type of proteins present in the test liquid.

\subsection{New Test Liquid for Prostheses Testing?}

The material costs for the test liquids as they were used in this study were about $55 € / \mathrm{L}$ (HiSi-mix, HA NCS RS), $11 € / L$ (HA BSA RS) and $85 € / L$ (HA BSA/IgG RS, HA BSA/IgG PL RS). The main factor influencing the material costs of the artificial synovial fluid was the IgG. However, if other suppliers are involved, the costs can be reduced to around $40 € / \mathrm{L}$ and thus even go under the costs for the HiSi-mix. In this calculation only the raw material costs were taken into account, neither storing (capacity) nor preparation were added. The NCS has to be stored frozen and additionally each lot has to be evaluated. All the test liquids need preparation time of a few hours; there was no significant difference from one to the other.

The initial idea was to adjust the salt content with the use of RS. However, the XPS-analysis revealed that the proteins BSA and IgG contained additional salts, leading to higher salt concentrations in the synthetic synovial fluid than initially planned. Thus, for the recipe of the test liquid HA BSA RS, the RS should be diluted with deionised water and for the test liquids containing BSA/IgG deionised water instead of RS should be used. As in this study no antibacterial agents were used in order to mimic the synovial fluid as close as possible (except for the HiSi-mix), silver wires were introduced 
during wear tests, releasing silver ions. A limitation of this study was that the bacterial growth was not measured. Since bacterial growth could affect the results [81,82], the use of this approach with silver wires is not suitable for joint simulators, especially because much more liquid is used. Thus, the use of antibacterial agents should be determined regarding their influence on the tribological performance.

The advantage of the reproducible synthetic synovial fluid is that it would allow a comparison between the results obtained by different testing laboratories. The obtained wear rates of UHMWPE pins on $\mathrm{CoCr}$ discs were similar to the use of the HiSi-mix, thus the results are comparable at least to some extent with earlier results. However, a new recipe containing antibacterial agents requires further investigations including hip simulator tests using different material pairings in order to validate the synthetic synovial fluid. A disadvantage of the synthetic synovial fluid is that the viscosity strongly depends on the molecular weight of the HA, thus - if changing to another batch of HA-the concentration of HA has to be determined performing by viscosity measurements. On the other hand, Guenther et al. showed that the concentration of HA did not affect wear [70]. However, adjusting the concentration of HA is far less work compared to a hip simulator study necessary to evaluate a different batch of NCS for the HiSi-mix.

\section{Conclusions}

In total, six test liquids were prepared using a step-by-step substitution of the existing NCS with the main constituents present in genuine synovial fluid. Viscosity, friction and wear measurements were performed for all liquids.

- Using $3 \mathrm{~g} / \mathrm{L} \mathrm{HA}$, the shear-dependent viscosity was in the range of human synovial fluid for diseased joints. The friction regime most likely changed from boundary lubrication at low sliding speeds to mixed lubrication at moderate sliding speeds, leading to lower friction coefficients and lower wear rates.

- Adding ions with the addition of RS led to an electrical screening of the dissociated acid groups over a shorter distance. Therefore, fewer hydrogen bonds between the HA chains were formed, leading to a slight decrease of the viscosity, which might explain the increase of wear.

- Replacing the NCS with selected proteins led to a further decrease of the viscosity, because the lyophilized proteins contained salts. With BSA as the only protein, the decrease of the viscosity led to higher friction at low sliding speeds. However, the wear tests were performed at higher sliding speeds of $20-40 \mathrm{~mm} / \mathrm{s}$ and thus were not affected by the higher friction at low sliding speeds. In contrast, the lowest wear rate was obtained with BSA as the only protein. With the addition of IgG and PL, the wear rate increased, whereas, with adding both of them, the most realistic synthetic synovial fluid was realised. This also had the advantage of the best reproducibility of friction and wear.

- The obtained wear particles were mostly granular particles together with fibrils. The size distribution was similar for all test liquids and comparable to the ones produced in vivo.

Based on this work, the test liquid containing $3 \mathrm{~g} / \mathrm{L} \mathrm{HA}, 19 \mathrm{~g} / \mathrm{L} \mathrm{BSA}, 11 \mathrm{~g} / \mathrm{L} \mathrm{IgG}, 0.1 \mathrm{~g} / \mathrm{L}$ PL and Ringer solution was the most comparable to genuine synovial fluid with a similar viscosity and similar lubrication properties, resulting in clinically relevant friction and wear coefficients. For 
prosthesis wear testing, the use of $3 \mathrm{~g} / \mathrm{L} \mathrm{HA}, 19 \mathrm{~g} / \mathrm{L} \mathrm{BSA}, 11 \mathrm{~g} / \mathrm{L} \mathrm{IgG}$ and $0.1 \mathrm{~g} / \mathrm{L} \mathrm{PL}$ together with an antimicrobial agent such as sodium azide is suggested. However, this recipe needs first to be validated. The cost for this synthetic synovial fluid is reasonable and comparable to existing test liquids used for prosthesis testing. Additionally, this synthetic synovial fluid can be reproduced independent from location and thus would allow a better comparison of tests performed in different laboratories.

\section{Acknowledgments}

The authors would like to thank Paul Brotschi and Marina Himmer for the sample production and for the polishing of the discs, Jorge Sague for his kind introduction in the tribometer, Jeannine Krieg for her help with the wear tests and Olivier Loeffel (all RMS Foundation) for taking the SEM pictures of the pins. A special thank goes to Thomas Schweizer (ETH Zurich, Switzerland) for his help with the viscosity measurements. Marc Bohner, Lukas Eschbach and Thomas Imwinkelried are acknowledged for proof reading of the article (all RMS Foundation). Last but not least, the financial support of the RMS Foundation is gratefully acknowledged.

\section{Author Contributions}

Emely Lea Bortel and Roman Heuberger conceived and designed the experiments, Emely Lea Bortel and Baptiste Charbonnier performed the experiments, Emely Lea Bortel, Baptiste Charbonnier and Roman Heuberger analysed the data, Emely Lea Bortel and Roman Heuberger wrote the paper.

\section{Conflicts of Interest}

The authors declare no conflict of interest.

\section{References}

1. Bergmann, G.; Graichen, F.; Rohlmann, A. Hip joint loading during walking and running, measured in two patients. J. Biomech. 1993, 26, 969-990.

2. Kutzner, I.; Heinlein, B.; Graichen, F.; Bender, A.; Rohlmann, A.; Halder, A.; Beier, A.; Bergmann, G. Loading of the knee joint during activities of daily living measured in vivo in five subjects. J. Biomech. 2010, 43, 2164-2173.

3. ISO 14242-1:2014 Implants for Surgery_Wear of Total Hip-Joint Prostheses_Part 1: Loading and Displacement Parameters for Wear-Testing Machines and Corresponding Environmental Conditions for Test; ISO Copyright Office: Geneva, Switzerland.

4. ISO 14242-3:2009 Implants for Surgery_Wear of Total Hip-Joint Prostheses_Part 3: Loading and Displacement Parameters for Orbital Bearing Type Wear Testing Machines and Corresponding Environmental Conditions for Test; ISO Copyright Office: Geneva, Switzerland.

5. ISO 14243-1:2009 Implants for Surgery_Wear of Total Knee-Joint Prostheses_Part 1: Loading and Displacement Parameters for Wear-Testing Machines with Load Control and Corresponding Environmental Conditions for Test; ISO Copyright Office: Geneva, Switzerland. 
6. ISO 14243-3:2004 Implants for Surgery_Wear of Total Knee-Joint Prostheses_-Part 3: Loading and Displacement Parameters for Wear-Testing Machines with Displacement Control and Corresponding Environmental Conditions for Test; ISO Copyright Office: Geneva, Switzerland.

7. Dumbleton, J.H. Tribology of Natural and Artificial Joints; University of Michigan: Ann Arbor, MI, USA, 1981.

8. Saari, H.; Santavirta, S.; Nordstrom, D.; Paavolainen, P.; Konttinen, Y.T. Hyaluronate in total hip replacement. J. Rheumatol. 1993, 20, 87-90.

9. Noordin, S.; Schmalzried, T.P.; Campbell, P.; Amstutz, H.C. Synovial fluid from patients with prosthetic joint arthroplasty: Protein concentration and in vivo wear of polyethylene. In Proceedings of the Transactions of the 43rd Annual Meeting of the Orthopaedic Research Society, San Francisco, CA, USA, 9-13 February 1997; Volume 22, p. 769.

10. Guenther, L.E.; Pyle, B.W.; Turgeon, T.R.; Bohm, E.R.; Yss, U.P.W.; Schmidt, T.A.; Brandt, J.M. Biochemical analyses of human osteoarthritic and periprosthetic synovial fluid. Proc. Inst. Mech. Eng. Part H 2014, 228, 127-139.

11. McKellop, H.; Lu, B. Friction, lubrication and wear of polyethylene/metal and polyethylene/ceramic hip prostheses on a joint simulator. In Proceedings of the Fourth World Biomaterials Congress, Berlin, Germany, 24-28 April 1992; p. 118.

12. Oral, E.; Ghali, B.W.; Muratoglu, O.K. The elimination of free radicals in irradiated UHMWPEs with and without vitamin e stabilization by annealing under pressure. J. Biomed. Mater. Res. Part B Appl. Biomater. 2011, 97, 167-174.

13. Liao, Y.S.; McKellop, H.; Lu, Z.; Campbell, P.; Benya, P. The effect of frictional heating and forced cooling on the serum lubricant and wear of UHMW polyethylene cups against cobaltchromium and zirconia balls. Biomaterials 2003, 24, 3047-3059.

14. St. John, K.; Gupta, M. Evaluation of the wear performance of a polycarbonate-urethane acetabular component in a hip joint simulator and comparison with UHMWPE and cross-linked UHMWPE. J. Biomater. Appl. 2012, 27, 55-65.

15. Grupp, T.M.; Giurea, A.; Miehlke, R.K.; Hintner, M.; Gaisser, M.; Schilling, C.; Schwiesau, J.; Kaddick, C. Biotribology of a new bearing material combination in a rotating hinge knee articulation. Acta Biomater. 2013, 9, 7054-7063.

16. Heuberger, R.; Wahl, P.; Krieg, J.; Gautier, E. Low in vitro third-body wear on total hip prostheses induced by calcium sulphate used for local antibiotic therapy. Eur. Cell Mater. 2014, 28, 246-257.

17. Kaddick, C.; Wimmer, M.A. Hip simulator wear testing according to the newly introduced standard ISO 14242. Proc. Inst. Mech. Eng. Part H 2001, 215, 429-442.

18. Crockett, R.; Roba, M.; Naka, M.; Gasser, B.; Delfosse, D.; Frauchiger, V.; Spencer, N.D. Friction, lubrication, and polymer transfer between UHMWPE and CoCrMo hip-implant materials: A fluorescence microscopy study. J. Biomed. Mater. Res. A 2009, 89, 1011.

19. McNulty, D.; Swope, S.; Liao, Y.S.; McKellop, H.; Shen, F.-W.; Galvin, A.; Fischer, J. Multi-lab evaluation of hip simulator test conditions on relative wear rates of crosslinked polyethylenes. In Proceedings of the 52nd Annual Meeting of the Orthopaedic Research Society, Chicago, IL, USA, 19-22 March 2006; p. 649. 
20. Wang, A.; Polineni, V.K.; Essner, A.; Stark, C.; Dumbleton, J.H. The Impact of Lubricant Protein Concentration on the Outcome of Hip Joint Simulator Wear Testing. In Proceedings of the 25th Annual Meeting Transactions of the Society for Biomaterials, Providence, RI, USA, 28 April-2 May 1999; p. 178.

21. Saikko, V. Effect of lubricant protein concentration on the wear of ultra-high molecular weight polyethylene sliding against a CoCr counterface. J. Tribol. 2003, 125, 638-642.

22. Schwenke, T.; Wimmer, M.A.; Kaddick, C. Fluid composition influences wear testing of artificial knee implants. In Medical Device Materials II-Proceedings of the Materials and Processes for Medical Devices Conference 2004; Helmus, M., Medlin, D., Eds.; ASM International: Novelty, OH, USA, 24-27 August 2005; pp. 173-177.

23. Wang, A.; Essner, A.; Schmidig, G. The Effects of Lubricant Composition on in vitro Wear Testing of Polymeric Acetabular Components. J. Biomed. Mater. Res. B Appl. Biomater. 2003, $68,45-52$.

24. Brandt, J.M.; Charron, K.; Zhao, L.; MacDonald, S.J.; Medley, J.B. Calf serum constituent fractions influence polyethylene wear and microbial growth in knee simulator testing. Proc. Inst. Mech. Eng. Part H 2012, 226, 427-440.

25. Brandt, J.M.; Mahmoud, K.K.; Koval, S.F.; MacDonald, S.J.; Medley, J.B. Antimicrobial agents and low-molecular weight polypeptides affect polyethylene wear in knee simulator testing. Tribol. Int. 2013, 65, 97-104.

26. Takadama, H.; Mizuno, M. A simulated synovial fluid for wear characterization of artificial hip joints by a hip joint simulator. Key Eng. Mater. 2006, 309-311, 1273-1276.

27. Roba, M.; Naka, M.; Gautier, E.; Spencer, N.D.; Crockett, R. The adsorption and lubrication behavior of synovial fluid proteins and glycoproteins on the bearing-surface materials of hip replacements. Biomaterials 2009, 30, 2072-2078.

28. Brandt, J.M.; Brière, L.K.; Marr, J.; MacDonald, S.J.; Bourne, R.B.; Medley, J.B. Biochemical comparisons of osteoarthritic human synovial fluid with calf sera used in knee simulator wear testing. J. Biomed. Mater. Res. A 2010, 94, 961-971.

29. Balazs, E.A.; Watson, D.; Duff, I.F.; Roseman, S. Hyaluronic acid in synovial fluid. I. Molecular parameters of hyaluronic acid in normal and arthritis human fluids. Arthritis Rheum. 1967, 10, 357-376.

30. Binette, J.P.; Schmid, K. The proteins of synovial fluid: A study of the $\alpha 1 / \alpha 2$ globulin ratio. Arthritis Rheum. 1965, 8, 14-28.

31. Slack, S.M. Properties of Biological Fluids. In Biomaterial Science an Introduction to Materials in Medicine, 2nd ed.; Ratner, B.D., Hoffmann, A.S., Schoen, F.J., Lemons, J.E., Eds.; Elsevier: Philadelphia, PA, USA, 2004; pp. 813-817.

32. Yao, J.Q.; Blanchet, T.A.; Murphy, D.J.; Laurent, M.P. Effect of fluid absorption on the wear resistance of UHMWPE orthopedic bearing surfaces. Wear 2003, 255, 1113-1120.

33. Körperflüssigkeiten. In Wissenschaftliche Tabellen Geigy; Ciba-Geigy Limited: Basle, Switzerland, 1977.

34. Schurz, J.; Ribitsch, V.; Rainer, F. Rheologische Untersuchungen an Synovia und Synoviamodellen. Rheol. Acta 1979, 18, 139-150. 
35. Ragan, C.; Meyer, K. The hyaluronic acid of synovial fluid in rheumatoid arthritis. J. Clin. Investig. 1949, 28, 56-59.

36. Nuki, G.; Ferguson, J. Studies on the nature and significance of macromolecular complexes in the rheology of synovial fluid from normal and diseased human joints. Rheol. Acta 1971, 10, 8-14.

37. Lee, D.W.; Banquy, X.; Das, S.; Cadirov, N.; Jay, G.; Israelachvili, J. Effects of molecular weight of grafted hyaluronic acid on wear initiation. Acta Biomater. 2014, 10, 1817-1823.

38. Kitano, T.; Ateshian, G.A.; Mow, V.C.; Kadoya, Y.; Yamano, Y. Constituents and pH changes in protein rich hyaluronan solution affect the biotribological properties of artificial articular joints. J. Biomech. 2001, 34, 1031-1037.

39. Hua, Z.K.; Su, S.H.; Zhang, J.H. Tribological study on new therapeutic bionic lubricants. Tribol. Lett. 2007, 28, 51-58.

40. Radin, E.L.; Paul, I.L.; Weisser, P.A. Joint lubrication with artificial lubricants. Arthritis Rheum. 1971, 14, 126-129.

41. Scholes, S.C.; Unsworth, A. The effects of proteins on the friction and lubrication of artificial joints. Proc. Inst. Mech. Eng. Part H 2006, 220, 687-693.

42. Hu, X.Q.; Wood, R.J.K.; Taylor, A.; Tuke, M.A. The tribological behaviour of different clearance MOM hip joints with lubricants of physiological viscosities. Proc. Inst. Mech. Eng. Part H 2011, 225, 1061-1069.

43. Nuki, G.; Ferguson, J.; Boyle, J.A.; Boddy, K. Rheological simulation of synovial fluid by a synthetic polymer solution. Nature 1969, 224, 1118-1119.

44. Smith, A.M.; Fleming, L.; Wudebwe, U.; Bowen, J.; Grover, L.M. Development of a synovial fluid analogue with bio-relevant rheology for wear testing of orthopaedic implants. J. Mech. Behav. Biomed. Mater. 2014, 32, 177-184.

45. Thompson, M.; Hunt, B.; Smith, A.; Joyce, T. Wear Tests of a Potential Biolubricant for Orthopedic Biopolymers. Lubricants 2015, 3, 80-90.

46. Sawae, Y.; Murakami, T.; Chen, J. Effect of synovia constituents on friction and wear of ultrahigh molecular weight polyethylene sliding against prosthetic joint materials. Wear 1998, 216, 213-219.

47. Yao, J.Q.; Laurent, M.P.; Johnson, T.S.; Blanchard, C.R.; Crowninshield, R.D. The influences of lubricant and material on polymer/CoCr sliding friction. Wear 2003, 255, 780-784.

48. Schmid, V. Tribometer zur Untersuchung von biologischem und synthetischem Knorpel. Bachelor Thesis, Bern University of Applied Sciences, Berne, Switzerland, 2008.

49. ISO 14242-2:2000 Implants for Surgery_Wear of Total Hip-Joint Prostheses_Part 2: Methods of Measurements; ISO Copyright Office: Geneva, Switzerland.

50. Beamson, G.; Briggs, D. High Resolution XPS of Organic Polymers; John Wiley \& Sons Ltd: Chichester, UK, 1992.

51. Moulder, J.F.; Stickle, W.F.; Sobol, P.E.; Bomben, K.D. Handbook of X-Ray Photoelectron Spectroscopy; Physical Electronics, Inc.: Eden Prairie, MN, USA, 1995.

52. Stribeck, R. Die wesentlichen Eigenschaften der Gleit- und Rollen-lager. Z. Ver. Dtsch. Ing. 1902, $46,1341-1348$.

53. Data Sheet Ticona GUR 1020; Ticona: Florence, KY, USA, 2011. 
54. Bortel, E. Development of a Test Fluid to Mimic the Synovia for the Tribological Testing of Materials for Joint Replacements. Diploma Thesis, TU Hamburg, Germany \& RMS Foundation, Bettlach, Switzerland, 2011.

55. Cooke, A.F.; Dowson, D.; Wright, V. The rheology of synovial fluid and some potential synthetic lubricants for degenerate synovial joints. Eng. Med. 1978, 7, 66-72.

56. Seller, P.C.; Dowson, D.; Wright, V. The rheology of synovial fluid. Rheol. Acta 1971, 10, $2-7$.

57. Roba, M. Interaction of Synovial Liquid Components with Artificial Hip-Joint Materials. PhD Thesis, ETH Zurich, Switzerland, 2009.

58. Scholes, S.C.; Unsworth, A.; Goldsmith, A.A.J. A frictional study of total hip joint replacements. Phys. Med. Biol. 2000, 45, 3721-3735.

59. Kurtz, S.M.; Gawel, H.A.; Patel, J.D. History and systematic review of wear and osteolysis outcomes for first-generation highly crosslinked polyethylene. Clin. Orthop. Relat. Res. 2011, 469, 2262-2277.

60. Hall, R.M.; Unsworth, A. Wear in retrieved Charnley acetabular sockets. Proc. Inst. Mech. Eng. Part H 1996, 210, 197-207.

61. Forsey, R.W.; Fisher, J.; Thompson, J.; Stone, M.H.; Bell, C.; Ingham, E. The effect of hyaluronic acid and phospholipid based lubricants on friction within a human cartilage damage model. Biomaterials 2006, 27, 4581-4590.

62. Swann, D.A.; Radin, E.L.; Nazimiec, M. Role of hyaluronic acid in joint lubrication. Ann. Rheum. Dis. 1974, 33, 318-326.

63. Serro, A.P.; Degiampietro, K.; Colaço, R.; Saramago, B. Adsorption of albumin and sodium hyaluronate on UHMWPE: A QCM-D and AFM study. Colloids Surf. B 2010, 78, 1-7.

64. Hutchings, I.M. Tribology_Friction and Wear of Engineering Materials. ButterworthHeinemann Ltd: London, UK, 1992.

65. Unsworth, A.; Pearcy, M.J.; White, E.F.T.; White, G. Soft layer lubrication of artificial hip joints. In Proceedings of the Institution of Mechanical Engineers International Conference: TribologyFriction, Lubrication and Wear; Institution of Mechanical Engineers: London, UK, 1987; pp. 715 724.

66. Smith, S.L.; Ash, H.E.; Unsworth, A. A tribological study of UHMWPE acetabular cups and polyurethane compliant layer acetabular cups. J. Biomed. Mater. Res. 2000, 53, 710-716.

67. Scholes, S.C.; Smith, S.L.; Ash, H.E.; Unsworth, A. The lubrication and friction of conventional UHMWPE, novel compliant layer, and hard bearing surfaces for use in total hip prostheses. In Friction, Lubrication and Wear of Artificial Joints; Hutchings, I.M., Ed.; Professional Engineering Publishing: Bury St Edmunds/London, UK, 2003; pp. 59-74.

68. Jalali-Vahid, D.; Jagatia, M.; Jin, Z.M.; Dowson, D. Prediction of lubricating film thickness in UHMWPE hip joint replacements. J. Biomech. 2001, 34, 261-266.

69. Mavraki, A.; Cann, P.M. Lubricating film thickness measurements with bovine serum. Tribol. Int. 2011, 44, 550-556.

70. Guenther, L.E.; Turgeon, T.R.; Bohm, E.R.; Brandt, J.M. The biochemical characteristics of wear testing lubricants affect polyethylene wear in orthopaedic pin-on-disc testing. Proc. Inst. Mech. Eng. Part H 2015, 229, 77-90. 
71. Widmer, M.R.; Heuberger, M.; Vörös, J.; Spencer, N.D. Influence of polymer surface chemistry on frictional properties under protein-lubrication conditions: Implications for hip-implant design. Tribol. Lett. 2001, 10, 111-116.

72. Karuppiah, K.S.K.; Sundararajan, S.; Xu, Z.H.; Li, X. The effect of protein adsorption on the friction behavior of ultra-high molecular weight polyethylene. Tribol. Lett. 2006, 22, 181-188.

73. More, N.S.; Diomidis, N.; Paul, S.N.; Roy, M.; Mischler, S. Tribocorrosion behavior of $\beta$ titanium alloys in physiological solutions containing synovial components. Mater. Sci. Eng. C 2011, 31, 400-408.

74. Wang, A.; Essner, A.; Stark, C.; Dumbleton, J.H. Comparison of the size and morphology of UHMWPE wear debris produced by a hip joint simulator under serum and water lubricated conditions. Biomaterials 1996, 17, 865-871.

75. Brandt, J.M.; Charron, K.D.J.; MacDonald, S.J.; Medley, J.B. Mass gain behaviour of tibial polyethylene inserts during soak testing. Proc. Inst. Mech. Eng. Part H 2011, 225, 324-331.

76. Mabrey, J.D.; Afsar-Keshmiri, A.; Engh, G.A.; Sychterz, C.J.; Wirth, M.A.; Rockwood, C.A.; Mauli Agrawal, C. Standardized analysis of UHMWPE wear particles from failed total joint arthroplasties. J. Biomed. Mater. Res. 2002, 63, 475-483.

77. Tipper, J.L.; Galvin, A.L.; Williams, S.; McEwen, H.M.J.; Stone, M.H.; Ingham, E.; Fisher, J. Isolation and characterization of UHMWPE wear particles down to ten nanometers in size from in vitro hip and knee joint simulators. J. Biomed. Mater. Res. Part A 2006, 78, 473-480.

78. Elfick, A.P.D.; Green, S.M.; Krikler, S.; Unsworth, A. The nature and dissemination of UHMWPE wear debris retrieved from periprosthetic tissue of THR. J. Biomed. Mater. Res. Part A 2003, 65, 95-108.

79. Šlouf, M.; Šloufová, I.; Horák, Z.; Štépánek, P.; Entlicher, G.; Krejčík, M.; Radonský, T.; Pokorný, D.; Sosna, A. New fast method for determination of number of UHMWPE wear particles. J. Mater. Sci. Mater. Med. 2004, 15, 1267-1278.

80. Billi, F.; Benya, P.; Kavanaugh, A.; Adams, J.; Ebramzadeh, E.; McKellop, H. The John Charnley award: An accurate and sensitive method to separate, display, and characterize wear debris: Part 1: Polyethylene particles. Clin. Orthop. Relat. Res. 2012, 470, 329-338.

81. Brandt, J.M.; Vecherya, A.; Guenther, L.E.; Koval, S.F.; Petrak, M.J.; Bohm, E.R.; Wyss, U.P. Wear testing of crosslinked polyethylene: Wear rate variability and microbial contamination. J. Mech. Behav. Biomed. Mater. 2014, 34, 208-216.

82. Wimmer, M.A.; Sah, R.; Laurent, M.P.; Virdi, A.S. The effect of bacterial contamination on friction and wear in metal/polyethylene bearings for total joint repair-A case report. Wear 2013, $301,264-270$.

(C) 2015 by the authors; licensee MDPI, Basel, Switzerland. This article is an open access article distributed under the terms and conditions of the Creative Commons Attribution license (http://creativecommons.org/licenses/by/4.0/). 